REVIEW

\title{
Sculpting life
}

\section{Bernini and the Birth of Baroque Portrait Sculpture}

Curators: Catherine Hess, Andrea Bacchi, Jennifer Montagu

Organized by the J. Paul Getty Museum in association with the National Gallery of Canada

The National Gallery of Canada

Nov. 28, 2008-Mar. 8, 2009

$\mathrm{F}$ irst, a heartfelt thank you to the anonymous looter who made this exhibit possible. Last year the J. Paul Getty Museum in Los Angeles returned 40 pieces of dubious provenance to Italy and in a gracious gesture of reconciliation, the Italians put together this travelling show.

And what a show it is. Not only portrait busts and sketches by Gian Lorenzo Bernini (1598-1680), but sculptures by contemporaries whose works occasionally surpass that of the master himself. Still, it's the imprint of this giant of the Italian Baroque that binds the exhibit together. Without his extraordinary creativity his disciples would have been trapped in a moribund style.

Bernini was the most successful architect of 17 th-century Rome, renowned for his monumental sculptures and church architecture, including, most memorably, the huge colonnade that embraces St. Peter's Square. His talents had an equally large and expansive reach. Besides being an architect, he was a playwright, theatrical designer, painter and intimate of popes and kings. The portrait busts were a mere sideline, but as with everything he did, he took the genre in a new direction and influenced a generation.

What distinguished his work was the injection of movement and life into a hitherto static art form. Robes swirl and dance as if caught by the wind. Heads tilt inquisitively to the side, lips

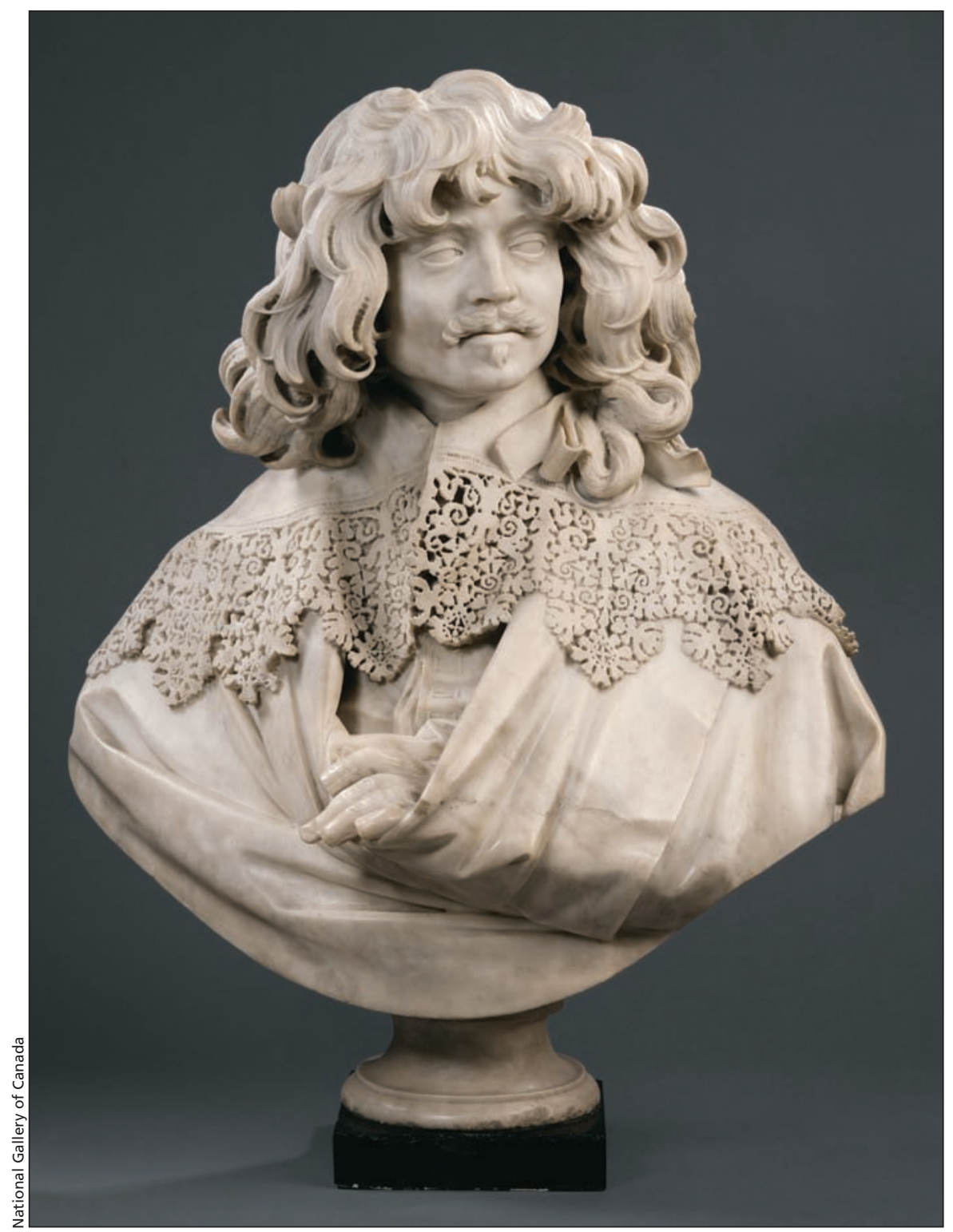

Gian Lorenzo Bernini, Portrait of Thomas Baker (1637-1638). Marble. 135 (height) $\times$ 70 (width) $\times 40$ (depth) cm. Victoria and Albert Museum, London, England. Although marble busts date from antiquity, Bernini brought a fluidity and realism to the form that, some argue, has yet to be replicated.

apart, as if they're about to speak. In some cases the irises and pupils of the eyes are deeply carved so that shadows give them the illusion of depth and reflectivity. You can see tiny hairs on the cheeks of Alexander VII, chiselled with clinical fastidiousness. These works are as lifelike as any sculptor - even Michelangelo - has achieved to date.

The amazing thing is that these are 


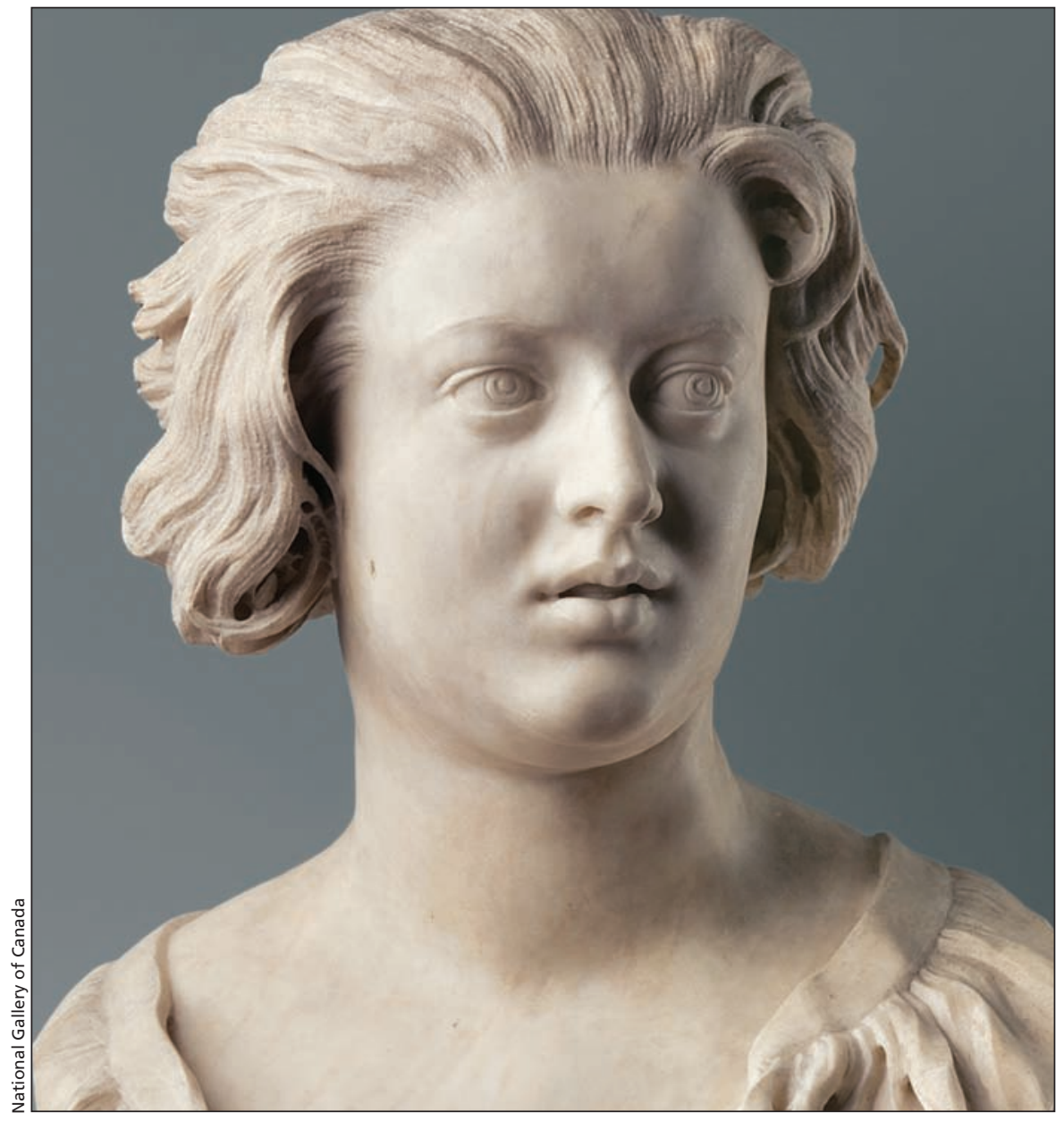

Gian Lorenzo Bernini, Portrait of Costanza Bonarelli (1636-1638). Marble. 80 (height) $\times 70$ (width) $\times 20$ (depth) $\mathrm{cm}$. Museo Nazionale del Bargello, Florence, Italy. This sensuous likeness of Bernini's lover is a startling testament to the artist's ability to capture his subjects in action. Lips gently parted, Bonarelli appears to be on the verge of speaking.

enormous talent. This small masterpiece traces the physiognomy of a nameless attendant in the Duke's retinue - a late-middle-aged man with proportionate dwarfism. The first question is of course, "Why him?" In this roomful of popes and kings, a servant?

The answer is the sculpture itself This tiny fellow positively radiates personality - a canny intelligence mixed with a wary deference. This was a man who could tiptoe through the minefield of 17th-century court politics and turn a disability into a strategic advantage. To Duquesnoy he must have been an irresistible subject.

It's tempting to imagine what Bernini would have produced had he been alive today. Compare his work to that of a realist sculptor such as Ron Mueck, whose

not only precise, literal likenesses. They exude a convincing sense of personality, all the more impressive when you realize that many of the busts were carved using paintings by other artists as reference, not the living subject. In some cases, the subject had been dead for many years and he had to rely on a death mask.

His contemporary and competitor for the same slice of patronage pie, François Duquesnoy, is hardly a name that rings down the ages, but, who knows, perhaps it should. Spend a few minutes looking at his bust, $A$ Dwarf in the Service of the Duke de Créquy, and it's unlikely you'll ever forget his

Gian Lorenzo Bernini, Maffeo Barberini, Pope Urban VIII (c. 1632). Marble. 94.7 (height) $\times 68.8$ (width) $\times 34.3$ (depth) $\mathrm{cm}$. National Gallery of Canada, Ottawa, Ontario. Remarkably, Bernini created the illusion of flesh from stone.

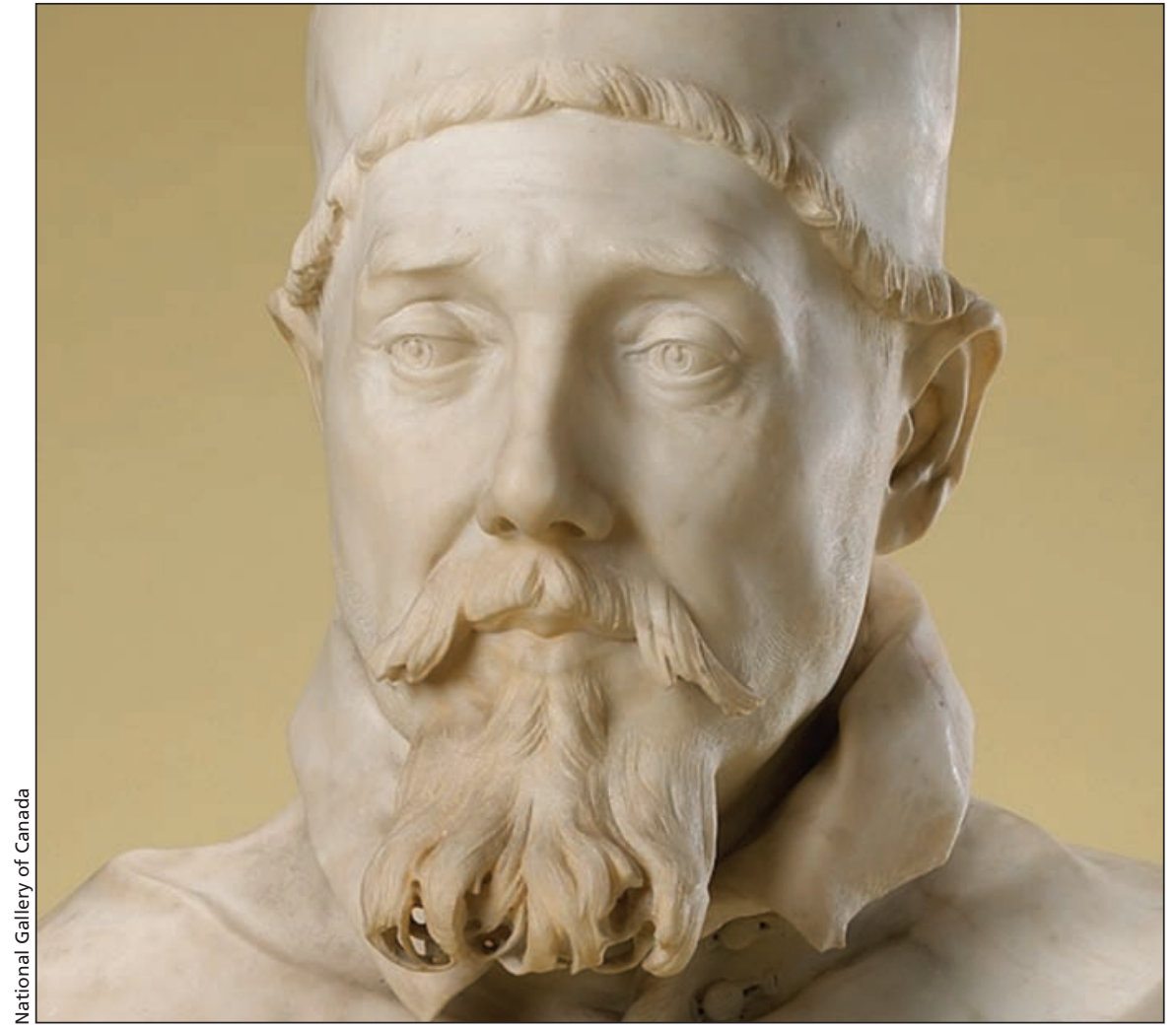

CMAJ • FEBRUARY 3, $2009 \bullet 180(3)$

( 2009 Canadian Medical Association or its licensors 


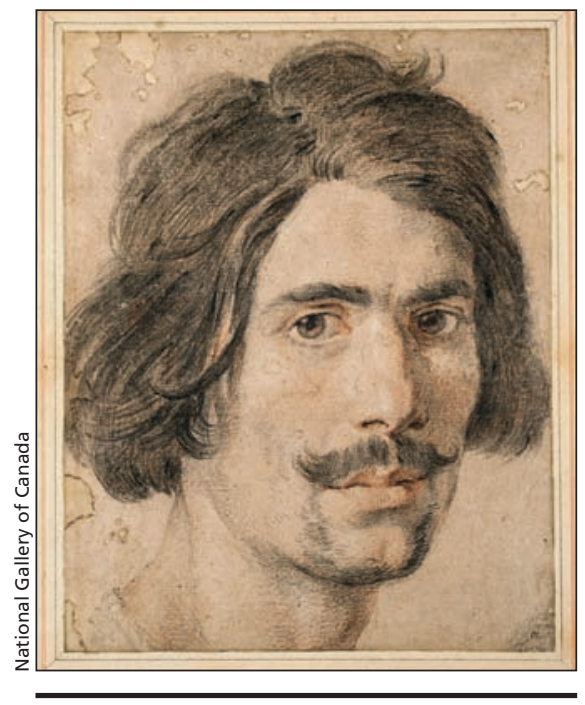

Gian Lorenzo Bernini, Self-Portrait (c. 1625). Black and red chalk, heightened with white chalk. $27.5 \times 21.5 \mathrm{~cm}$. Ashmolean Museum of Art and Archaeology, Oxford, England. Purchased (Hope Fund), 1944. This is the first major Bernini exhibition seen outside Italy.

art was featured at the national gallery last year (CMAJ 2007;176:1314-5), and it seems unlikely he would have embraced his dark, introspective formulations. Bernini was too much a man of his era - the Baroque, with its hallmarks of exuberance, unbounded confidence, drama and religious certainty.

More likely he would have felt more comfortable as an architect, designing buildings with wild, roiling surfaces á la Frank Gehry. In fact, if you were to enlarge some of his drapery to buildingsized proportions, you'd have a pretty close approximation of a Gehry facade.

The principal difference between now and then, though, is that Bernini's primary medium, in both architecture and sculpture, was marble. These busts are nearly 400 years old. Somehow it's hard to imagine the work of today's artists being in such pristine condition even 100 years from now.

\section{Alan King BA}

Writer and artist

Ottawa, Ont.

Mr. King is an Ottawa artist and writer, whose most recent accomplishment is playing the last 2 movements of Beethoven's piano sonata, Opus 111 (minus those impossible right-hand trills).

\section{REVIEW}

\section{In pursuit of equity}

\author{
Health Inequality: Morality and \\ Measurement \\ Yukiko Asada \\ University of Toronto Press; 2007 \\ 294 pp $\$ 55.00$
}

$\mathrm{M}$ any of us working in health care are concerned about health equity. However, we often lack a clear understanding of what equity means and how it should be measured, which makes it impossible to judge whether our work serves to reduce or to increase inequity. Health Inequality: Morality and Measurement will illuminate readers on these concepts.

This book's ambitious aim is to "build a theoretical and analytical framework for measuring health inequality." The author, Dr. Yukiko Asada, defines health inequity as "the moral or ethical dimension of health inequality," that is, those health inequalities that not only exist, but "are of moral concern due to the value we place on health." She provides justification for why the distribution of health across a population may be seen as a moral issue: that health is a special good, as an important component of wellbeing, which is necessary and useful for a good life; that health equity plays an important role in the general pursuit of justice and equality, though may not have a special status; and that health inequality is an indicator of general social justice.

The book begins with an exploح ration of which health distributions are equitable, considering, for example, inequality that results from causes that are the responsibility of society as opposed to inequality that may result from individual choice. $\AA$ Asada then discusses which meas- urement strategies would be most appropriate to operationalize various concepts of equity and the complex process of summarizing a health distribution into one number. Finally, she conducts an empirical analysis of health inequity, leading readers step-by-step through an analysis of whether health equity changed in the United States from 1990 to 1995.

Throughout the book, Asada tackles fundamental questions about equity, such as whether we should consider determinants of health or functionality when we define health equity, whether we should compare equity across individuals or across groups of people within a society (such as racial or socio-economic groups), and whether we should measure the average health of a population or the proportion of people who meet a minimum standard of health. The discussion of these complex subjects is insightful and clear.

A challenge of this book, which may also be a strength, is that it bridges philosophy and quantitative methodology. So while Health Inequality: Morality and Measurement offers sound thinking and innovative approaches, the book demands a careful and dedicated reader to follow fairly sophisticated concepts and math. For such readers, the rewards are great.

\section{Fiona Kouyoumdjian MD MPH \\ Community medicine resident \\ Faculty of Medicine \\ University of Toronto \\ Toronto, Ont.}

Dr. Kouyoumdjian, who is interested in equity issues in determinants of health, health care access and health outcomes, is currently completing a residency in community medicine and a doctorate in epidemiology. 